Doc. dr. Strahinja Miljković, LL.D., Assistant Profesor, Faculty of Law in Kosovska Mitrovica, University of Priština Aleksandra Vasić, LL.M., Teaching Assistant, Faculty od Law, University of Niš

\title{
ON (UN)ENFORCEABILITY OF RESTRICTIVE CLAUSES IN PATENT LICENSE AGREEMENT ${ }^{1}$
}

\author{
UDK: 347. 77 \\ Primljeno: 1. 11. 2016. \\ Pregledni rad
}

License Agreement represents a legal institute which performs the constitutive transport of industrial property rights or an instrument that allows the connection of subjects that create intellectual resources with those that have technical and economic means for their exploitation. Licensing of new, protected inventions and their exploitation contribute undoubtedly to the overall social development.

The right to a patent guarantees its titular, for a certain period of time, the monopoly right to its exploitation, so that his titular right can be transferred to other persons under much more restrictive conditions than is usual for the transfer of other rights. A superior position of a licensor allows him to put the license acquirer in a more dependent position by entering different restrictive clauses that affect the freedom of economy and competitiveness at the licensee market into concerned License Agreement. Due to violation of free competition in the market certain restrictive clauses in Patent License Agreements are considered to be unenforceable from the standpoint of Competition law and, for the need of Legal certainty, they have to be suppressed at both national and international level.

Keywords: license agreement, patent, competition law, restrictive clauses, legal security.

\section{INTRODUCTION}

Bearing in mind that regulations governing the area of Intellectual Property rights and Competition law, unprofessionally viewed as two opposing branches of the law, if one takes into account the method by which relations in the market are being regulated, the authors of the Paper are trying to present the Patent License agreement as one of the contact points of these two branches of law. The Paper analyzes the basic features of Patent License agreement and sources of law used to regulate this legal concept in Serbian law. Moreover, we also analyzed the role of this contract in the Intellectual Property law and Competition law and an attempt to

1 This is a result of research on the project „Approxmation of the Serbian law wit the EU law”, funded by the Faculty of Law, University of Niš, during the period between 2013 and 2018. 
draw attention to the common goal that is being accomplished by using this legal concept.

Intellectual Property right consists of copyright and rights related to copyright, in the one hand, and Industrial Property rights, on the other hand. To analyze License agreements, rules that belong to the second group are important due to the fact that the objects of human creativity that are being protected by Industrial property rights standards achieve their purpose through the use in the course of trade.

\section{ABOUT THE LICENSE AGREEMENT}

The subject of the License agreement, as the basic legal instrument which may accomplish trading of protected Industrial Property rights, in Serbian law is regulated by the Law of Contract and Torts. Legal provisions have cited as the subject of the License agreement the exploitation of industrial property assets, for which it represents a common legal instrument of possession. It is stipulated by the law that the License agreement obligates the licensor to assign to the licensee, in whole or in part, the right of using the invention, technical knowledge and experience, trademark, design or model, while the licensee is obligated to pay a certain fee ${ }^{2}$ for it to him. Traffic of constitutive rights shall be made by this agreement, ie. from the subjective industrial property laws is carried out (derived) one or more property and legal powers which, as a new subjective right, constitute the name on behalf of the licensee, which does not affect the substance of the original law that continues to exist alongside with the license.

When disposing with this exclusive property and legal powers, the right of the licensee may be limited in many ways, i.e., may be defined in content, subject, territory and time. First, restrictions in content determine what property and legal powers are ceded by the agreement.

Further, with regard to the object of use, it is possible to identify specific actions necessary to use the patent that the licensee may carry out based on the contract.

The powers of the licensee may be limited territorially, in terms of determining the territorial scope of validity of property and legal powers that may be ceded by the contract.

Furthermore, the license agreement usually determines the duration timeframe of the property and legal powers ceded by the contract.

There are two types of license, exclusive and non-exclusive license (free). ${ }^{3}$ The main feature of an exclusive license is that the licensor must not exert himself or cede to a third party the same powers that have already been ceded to the licensee. In this regard, the exclusive licensee is authorized to solely perform ceded

Art.686, Law of Contract and Torts, Official Gazette of SFRY, no. 29/78.

Art. 689, Law of Contract and Torts, Official Gazette of SFRY, no. 29/78. 
powers, that enable his license to get the character of the exclusive laws. ${ }^{4}$ Since a monopoly on the agreed property and legal powers is provided to the licensee of an exclusive license (usually these are t powers related to the production and marketing of goods), hence the Patent License Agreement may affect competition in a particular market. ${ }^{5}$ Patent License Agreement aims to facilitate the traffic of patent protected inventions and connection of the patent right holder and those entities that have the necessary capacity of technical and economic resources for a successful exploitation of patented inventions and processes, resulting in creating a stimulating environment for overall social development and prosperity. However, besides improving its functioning, the Agreement on exclusive patent license may cause negative effects on the Competitive market participants.

Besides the fact that the Patent Lcense agreement is a legal relationship between two interested entities, the licensor and the licensee, it is also the instrument of goods traffic in the market. In the modern information society, the Industrial Property laws are regularly obtained and ceded at the International level, between entities from the highly developed countries that are capital exporters, and the least developed countries and developing countries that are mostly capital importers. Modern forms of technology can be transferred from one country to another independently, or through License agreements, or through cooperation, Agreement on leasing, franchising, direct foreign investment and the like.

Granted right to a patent provides to its titular certain market advantage over its competitors.

In some cases, this advantage, which is recognized to the titular by the legal norms of Intellectual Property laws, with the aim of encouraging intellectual creativity and enabling competition in the Intellectual Property market, can lead to a dominant position on the market of certain subjects.

It is therefore essential to, when assessing whether certain cessions of Patent License agreement are allowed or not, take into account not only the norms of Intellectual Property laws, but also the Competition laws. ${ }^{6}$ Certain provisions of the Patent License agreement, although not in contradiction with the rules of Intellectual property may represent some form of violating competition of market participants.

Since the right to patent guarantees to its titular monopoly right to exploitation within duration of patent protection, he is entitled to transfer that right to other persons under much more restrictive conditions than is normally allowed, and commonly used for the transfer of other laws. Conditions under which this agreement has been concluded are called restrictive clauses and the two contracting parties define with it the content of the exclusive powers that have to be ceded.

4 Further information on the term of exclusive licence: S. Marković, Patentno pravo, Nomos, Beograd, 199, 318-19.

5 C. Quigley, European Community Contact Law, Kluwer Law International, 1997, 375-376.

6 D. Popović, Isključiva prava intelektualne svojine i slobodna konkurencija, Faculty of Law, University of

Belgrade, Beograd, 2012, 21-22. 
If we consider that traffic of the patent laws, and other Intellectual Property laws, take place mainly at the International level, where as licensees the subjects from underdeveloped countries or developing countries emerge, which often have a strong interest and need for a specific patent, we may easily reach the conclusion that these subjects are in some way forced to accept all conditions that the licensor imposes in the License agreement. By using his superior position the licensor seeks to put the licensee in a very dependent position, which is achieved by entering into License agreement various restrictive clauses that restrict the economic freedom of the licensee and affect its competitiveness in the market.

From the standpoint of Competition law the restrictive clauses which appear in the Patent License agreement (or any other protected industrial property laws) may be permissible or impermissible. For example, the contract may envisage provisions that present the licensor effort to block further technological development and development of sold technology in order to keep, as long as possible, the license holder in dependent position; to restrict the purchase of equipment and materials abroad exclusively from the technology provider; to ban export on certain markets and the like.

Competition law considers some of these restrictive clauses inadmissible for the sake of violating free competition. More specifically, the illegal restrictive clause in the License agreement are the abuse of monopoly position because they go beyond the scope of exercising monopoly laws guaranteed to the patent titular by relevant regulations. The Licensor with these clauses makes the position of the licensee harder, since he keeps him in a dependent position and prevents him to appears as a potential competitor in the market. In this way the licensor virtually ensures its superior position in the market. Restrictive clauses are so numerous and diverse that it is difficult to perform their full and final enumeration, but the most typical and most common in the contracts have been presented in the Paper. However, even from the standpoint of this law the License agreements are not inadmissible forms of competition restrictions per se. It is necessary in this particular case to examine the anti-competitive effects that the License agreement has with respect to the market power that it brings. ${ }^{7}$

\section{DETERMINATION OF RESTRICTIVE CLAUSES IN SERBIAN REGULATIONS}

Although the legislator provides that contracting parties are obliged to adhere to the principle of good faith, this principle is often betrayed in the practice of License agreements.

D. Guellec, Patent Markets in the Global Knowledge Economy: Theory, Empirics and Public Policy Implications,

Cambridge University Press, 2014, 164. 

Zbornik radova Pravnog fakulteta u Splitu, god. 54, 3/2017., str. 637.- 644.

In order to prevent possible abuse of License agreements, the existence of appropriate legal regulations is necessary. When it comes to Serbian regulations, we can conclude that the lack of an appropriate legal framework enabled the transfer of technology by means of License agreements to be conducted without proper control, and thus this leads to the conclusion that the restrictive clauses were represented in the License agreements.

Within provisions of the Law of Contract and Torts that regulate the Licensing agreement the prohibition of entering the restrictive clauses in the two cases has been stipulated. Thus, the Law provides that the license to exploit the patented invention, samples or models cannot be completed for the time longer than duration of legal protection of these laws. ${ }^{8}$ Since the right to patent is a subjective right, which allows to its titular monopolistic use of the protected invention for a specified time, after the expiry of legal protection the patent becomes the common good. The Serbian Law on patents that regulates the legal protection of inventions, as in most modern Patent laws it has been stipulated that patent protection lasts for twenty years. ${ }^{9}$ Limited legal protection lifetime of patented inventions is the result of compromise between two contradictions, the right of the creator to results of his intellectual labor and the laws of the community to benefit from these results. Since it is the general rule that the right to a patent lasts for twenty years, and that after the expiry of this period it becomes a public good, the clause in the Patent License agreement that should allow to the licensor the right to the license fee after the expiry of the legal protection period would represent a classic example of abusing the right to a patent as the monopoly right.

Furthermore, Law of Contract and Torts prescribes that the right to use the license object can be territorially limited only if not contrary to the rules of the single market. ${ }^{10}$ The Constitution of the Republic of Serbia, in the part referring to the economic system of the country, stipulates that all participants have an equal position in the market. Also, the Constitution prohibits all acts that, contrary to law, restrict free competition by creating or abusing monopolistic or dominant position. ${ }^{11}$ The Legal Act that was enacted under the Constitution of 2006, which is still in the implementation is the Law on Protection of Competition, that sanctions actions and acts that lead to the limitation of the single (relevant) market. This regulation is for the most part based on the provisions of the Treaty on establishing the EU, in which the provisions on the protection of competition are divided into two groups: the regulations that apply to economic entities and regulations that apply to the state aid. ${ }^{12}$ Also, the Law on Protection of Competition is in conformity with the

8 Art. 688, Law of Contract and Torts, Official Gazette of SFRY, no. 29/78.

9 Art. 39, Law on Patents, Official Gazette of RS, no. 99/2011.

10 Art. 690, Law of Contract and Torts, Official Gazette of SFRY, no. 29/78.

11 Art 84, Constitution of the Republic of Serbia.

12 Art. $81-89$, Treaty on establishing. European Union-Consolidated Versions of the Treaty on European Union

and of the Treaty Establishing the European Community published in Official Journal of the EU, no. C 321E of 29.12.2006. 
provisions of TRIPS. For the purposes of this Act, as violation of the competition may be considered any act or action taken by the market participants that for the purpose or effect have or may have significant restriction, distortion or prevention of competition. ${ }^{13}$

In particular, in contractual relationships between market participants this is considered impermissible: a) direct or indirect determining of buying or selling prices or other trading conditions; b) restriction or control of production, markets, technical development or investment; v) applying of unequal business conditions to same transactions with respect to various market participants, where market participants are put into unfavorable position in relation to competitors; g) causing the conclusion of contracts or agreements by accepting additional obligations, which, by their nature and commercial usage and practice are not related to the subject of the agreement; d) sharing of markets or sources of procurement, if such proceedings have as their object or effect a significant restriction, violation or prevention of competition on the territory of the Republic of Serbia. ${ }^{14}$ The mentioned restrictive clauses are prohibited and null and void, except in cases when it comes to exemptions. Namely, the Serbian legislator foresees two types of exceptions: cases of individual exemption from banning to be decided by the Commission for Protection of Competition ${ }^{15}$ and exemptions by category, as determined by the Government of the Republic of Serbia. ${ }^{16}$ The aforementioned authorities make the decision on exclusion, bearing in mind if clauses could contribute to improving the production and transport, and encouraging technical or economic progress, providing the consumers with a fair share of the benefits, provided they do not impose restrictions to the market participants that are not necessary to achieve the objective of the agreement or that do not exclude competition in the relevant market or in a substantial part of it. ${ }^{17}$ So, from the standpoint of the Law on Protection of Competition Patent License agreements containing restrictive clauses are not inadmissible forms of restrictions of competition per se. It is necessary in this case to examine the anti-competitive effects of the License agreement with respect to the market power that brings.

After examining the solutions that the Competition Protection Commission has brought in relation to individual exemptions from banning the restrictive agreements starting with entering into force of the Law on Protection of Competition, we learn that there have been no solutions that are exempt from banning a restrictive clause in a Patent License agreement. It should be mentioned that the current Law on Patents, in the title, which is called the Trffic law regulates the concept of Patent license, but does not talk about restrictive clauses. Specifically, the Law stipulates that the subject ceded on the basis of a License agreement can be laws in the application

13 Art. 9, Law on Protection of Competition.

14 Art. 10, Law on Protection of Competition.

15 Art. 12, Law on Protection of Competition.

16 Art. 13, Law on Protection of Competition.

17 Art 11, Law on Protection of Competition, Official Gazette of RS, no. 51/2009. 
form, as well as the right to a patent or petty patent, while the contract must be concluded in writing and contain the essential elements defined in this Law. In addition, if the License agreement is to make legal effect to third parties it must be registered in the adequate Registry at the competent authority, and in this case it is the Department of Intellectual Property. ${ }^{18}$ On issues related to the License Patent agreement not regulated by this law, provisions of the Law of Contract and Torts are applied, and the Law of Contract and Torts referring to restrictive clauses in License agreements is applied when it comes to the transfer of laws to the patent.

\section{CONCLUSION}

Whether it is about the rules governing intellectual property or Competition law, it is certain that the aim is a real, effective regulation of relations between participants in legal transactions.

At first sight if we look from the unprofessional point of view, it seems that these two branches that have become increasingly relevant in the Serbian legal system, make the opposing branches of law.

However, we believe that the present concept of restrictive clauses that can very often be found in the License agreements of Industrial Property laws, and mostly in Patent licenses, is a good example of how various methods of legal regulation of certain social relations can serve the same goal, which is to maximize markets efficiency that will inevitably have a positive impact on the development of entrepreneurship and encouragement of foreign investment.

License Agreement in our country is one of the main legal instruments used for transferring laws to commercial exploitation of patented inventions and the laws in patent application forms. By analyzing current solutions in Serbian law related to the Patent License concept the authors have come to the conclusion that, given the importance of those License agreements to the development of domestic economy, it would be expedient that Serbia should get a new Law on the Technology transfer that would have to include legal solutions to meet modern economic life. The new law should, among other things, contain norms that regulate in detail the License agreement concept, and to predict the obligation that each completed License agreement must be submitted to the competent authority that deals with the competition protection on the market.

18 Art. 46. Law on Patents, Official Gazette of RS, no. 99/2011. 


\section{O (NE)DOPUŠTENOSTI RESTRIKTIVNIH KLAUZULA U UGOVORU O LICENCI PATENTA}

Ugovor o licenci predstavlja pravni institut kojim se vrši konstitutivni promet prava industrijske svojine, odnosno instrument kojim se omogućava povezivanje subjekata koji stvaraju intelektualna dobra sa onima koji raspolažu tehničkim i ekonomskim sredstvima za njihovo iskorišćavanje.

Pravo na patent garantuje svom titularu, za određeni vremenski period, monopolsko pravo njegovog iskorišćavanja, tako da titular svoje pravo može prenositi drugim licima pod znatno restriktivnijim uslovima nego što je to uobičajeno za prenos drugih prava. Superiorniji položaj davaoca licence omogućava mu da sticaoca licence stavi u što zavisniji položaj tako što se u predmetni ugovor o licenci unose različite restriktivne klauzule koje utiču na slobodu privredjivanja i konkurentnost korisnika licence. Zbog narušavanja slobodne konkurencije na tržištu pojedine restriktivne klauzule u ugovorima o licenci patenta smatraju se nedopuštenim sa stanovišta prava konkurencije, te se zbog potrebe pravne sigurnosti, suzbijaju kako na nacionalnom, tako i na medjunarodnom planu.

Ključne reči: ugovor o licenci, patent, pravo konkurencije, restriktivne klauzule, pravna sigurnost 